Résumés des conférences et travaux

\title{
Initiation au néo-égyptien
}

\section{Serge Rosmorduc}

\section{(2) OpenEdition \\ Journals}

Édition électronique

URL : https://journals.openedition.org/ashp/137

DOI : 10.4000/ashp.137

ISSN : 1969-6310

Éditeur

Publications de l'École Pratique des Hautes Études

\section{Édition imprimée}

Date de publication : 1 octobre 2008

Pagination : 1

ISSN : 0766-0677

\section{Référence électronique}

Serge Rosmorduc, «Initiation au néo-égyptien », Annuaire de l'École pratique des hautes études (EPHE), Section des sciences historiques et philologiques [En ligne], 139 | 2008, mis en ligne le 13 novembre 2008, consulté le 12 juillet 2021. URL : http://journals.openedition.org/ashp/137 ; DOI : https://doi.org/ $10.4000 /$ ashp. 137 


\title{
INITIATION AU NÉO-ÉGYPTIEN
}

\author{
Chargé de conférences : M. Serge Rosmorduc
}

Programme de l'année 2006-2007 : I. Langue et grammaire : introduction à la grammaire du néo-égyptien; formes autonomes (suite); formes continuatives. - II. Étude de textes : textes relatifs à l'administration des champs.

Cette année, nous sommes passés à deux heures de cours hebdomadaires, ce qui a permis de dégager du temps pour l'initiation des grands débutants. Une semaine sur deux, le cours a donc été destiné à ceux-ci, et a porté presque exclusivement sur la grammaire, l'autre cours étant partagé entre grammaire et texte. Le programme, en grammaire, a abordé les temps seconds, les formes continuatives (séquentiel et conjonctif), ainsi que l'usage des pseudo-auxiliaires. Nous avons par ailleurs essentiellement étudié des textes portant sur les problèmes d'administration des champs, textes d'origines diverses (véritables documents administratifs et «miscellanées »). Outre ceux-ci, nous avons étudié la stèle de Penboui, dans la collection Burrel, qui relève du dossier de la piété personnelle. L'auteur de la stèle adresse des louanges à la Touéris, probablement pour la remercier de l'avoir " guéri » d'une stérilité supposée, consécutive à quelque méfait envers la déesse. 